\title{
FACTORS AFFECTING SECURITIES PRICES: THEORETICAL VERSUS PRACTICAL APPROACH
}

\author{
Manuela Tvaronavičiené ${ }^{1}$, Julija Michailova ${ }^{2}$ \\ Vilnius Gediminas Technical University, Sauletekio al. 11, LT-10223 Vilnius, Lithuania \\ E-mail:1'manuela@vv.vtu.lt,.'julija_michailova@yahoo.com \\ Received 5 May 2006; accepted 4 September 2006
}

\begin{abstract}
Securities market has been influenced by entirety of factors, which roughly could be divided into various groups. In order to show complexity of phenomenon authors strive to overview theories of stock price behaviour. Taking into account, that various authors present rather controversial empirical evidences of certain factors impact on stock' prices, authors of this paper try to test some relationships practically. Statistical analysis aiming to evaluate quantitatively the dependence of stock index on some chosen statistically measurable factors is being performed. For the latter purpose stock prices of Lithuanian companies and such macroeconomic variables as foreign direct investment, state budget revenue and expenditure, gross domestic product, price index of consumer goods and services, money in a broad sense, average profitability of governmental bonds and inflation have been employed.
\end{abstract}

Keywords: stock prices, securities price factors, macroeconomic variables.

\section{Stock Prices Theories}

Before we start the review of variables that have impact on stock price changes let us overview main theories explaining stock price changes and formation.

1. The Efficient Market Hypothesis (EMH) is based on assumption that there are large numbers of rational, profit-seeking investors in the marketplace who react quickly to the release of new information. As new information about stocks appears, investors reassess the intrinsic value of stock and adjust the price accordingly. Therefore, at any point in time a stock price is an unbiased reflection of all available information and represents the best estimate of the stock's true value (Cleary, 2001).

A distinction between three forms of EMH is being made: a) the weak form, b) the semi-strong form, and c) the strong form. However, it is the semi-strong form of EMH that has formed the basis for most empirical research (Russel, Torbey, 2002). The strong form of market efficiency states that securities prices reflect all available information, including private information.
However Russel and Torbey find that Seyhun in his works, dated 1986 and 1998, provides sufficient evidence that insiders profit from trading on information not incorporated into prices (Russel, Torbey, 2002). Hence the strong form of market efficiency does not hold in the real world. The semi-strong form of EMH asserts that securities prices reflect all publicly available information. There are no undervalued or overvalued securities and thus, trading rules are incapable of producing superior returns. When new information is released, it is fully incorporated into the price rather speedily. The availability of intraday data enabled tests which offer evidence of public information impacting stock prices within minutes (Russel, Torbey, 2002). The weak form of the market efficiency hypothesis suggests that past prices or returns reflect future prices or returns (Russel, Torbey, 2002). However, the concept of the weak form can be expanded to include predicting future returns with the use of accounting for macroeconomic variables (Russel, Torbey, 2002). The disagreement on the degree of market efficiency, which should be tested or included in empirical research, continues through years. 
2. The Random Walk Theory postulates that new information concerning stocks is disseminated randomly over time. Therefore, price changes are random and bear no relation to previous price changes (Cleary, 2001). So the theory tells us that if stock prices follow a random walk, the market can be supposed to be efficient in the sense that it discounts all available information (Dockery et al., 2001). This hypothesis has been widely tested in both developed and emerging capital markets (Dockery et al., 2001). Overall, however, the evidence has been somewhat mixed (Dockery et al., 2001), i.e. several researchers find no evidence of patterns in stock prices, while others support the RWH (random walk theory).

3. The Rational Expectations Hypothesis is based on the assumption that people are rational and make intelligent economic decisions after weighing all available information and will use it intelligently in their own self interest. Past mistakes can be avoided by using the information to anticipate change (Cleary, 2001).

4. Behavioural Finance Theory is very different from the random walk and the efficient market theories (Investing internet site http://www.investorguide.com/ igustockmarket.html). A theory stating that there are important psychological and behavioural variables involved in investing in the stock market that provide opportunities for smart investors to profit (An investing glossary on the web http://www.investorwords.com). For example, when a certain stock or sector becomes "hot" and prices increase substantially without a change in the company's fundamentals, behavioural finance theorists would attribute this to mass psychology (also known as the "follow the herd instinct"). They therefore might see the stock in the long term, knowing that eventually the psychological bubble will burst and they will profit (Investing internet site http:// www.investorguide.com; an investing glossary on the web http://www.investorwords.com). So the proponents of this theory explain changes in stock market prices by investors' psychology, rather than statistical data.

Opponents of the three former theories state that there is not the only one true value of a stock price, and that investors do not always act rationally (see the Behavioural Finance Theory). In times of uncertainty, other factors such as mass investor psychology and the influence of program trading (Cleary, 2001) also affect market prices. Mass investor psychology may cause market participants to act irrationally. Therefore changes in investors' behaviour, are causing prices to tumble (Cleary, 2001) or rocket up suddenly.
In conclusion, we see, that all these theories explain changes in stock prices by changes in the expectations of market participants, which should be seen as psychological or human factors affecting fluctuations in securities market.

Stock prices reflect expectations of earnings, dividends, and interest rates. As investors attempt to estimate these future variables, their stock price decisions reflect expectations for future economic activity, not current activity (Reilly, Brown, 2003).

To test for rationality of market behaviour (i.e. examining the volatility of share prices relative to the volatility of the fundamental variables that affect share prices) volatility tests are used. The empirical evidence provided by volatility tests, suggests that movements in stock prices cannot be attributed merely to the rational expectations of investors, but also involves an irrational component (Russel, Torbey, 2002).

Shleifer and Summers (1990) state that there are two types of investors in the market: 1) rational speculators or arbitrageurs who trade on the basis of information and 2) noise traders who trade on the basis of imperfect information.

An observation of investors' trading strategies (such as trend chasing) in the market provides evidence for decision making being guided by "noise" rather than by the rational evaluation of information. Further support is provided by professional financial analysts spending considerable resources in trying to predict both the changes in fundamentals and also possible changes in sentiment of other investors (Russel, Torbey, 2002). Tracking these possible indicators of demand makes no sense if prices responded only to fundamental news and not to investor demand. They make perfect sense, in contrast, in a world where investor's sentiment moves prices and so predicting changes in this sentiment pays (Shleifer, Summers, 1990).

Black in his "Noise" (Black, 1986) also argues that noise traders play a useful role in promoting transactions (and thus, influencing prices) as informed traders like to trade with noise traders who provide liquidity. So long as risk is rewarded and there is limited arbitrage, it is unlikely that market forces would eliminate noise traders and maintain efficient prices.

Many factors affect expectations and thus play a part in determining securities prices. As it was mentioned in our article, we will review only some of them which are: monetary policy, external events, fiscal policy, business cycles, dividends, inflation, and mass psychology. 


\section{Impact of Macroeconomic Factors}

Many researchers have determined that macroeconomic variables play an important role in determining stock prices and have found macroeconomic variables to be important in regard to stock market. In our empirical part we rely exclusively on chosen macroeconomic factors.

Numerous studies have analyzed existence of the relationship between money supply and stock price changes. Special attention was paid to determination of whether changes in money supply precede changes in stock prices. Results of such researches tend to change from time to time (Reilly, Brown, 2003). Various studies supported the view that there is a strong leading relationship between changes in money supply and stock prices. Such results implied that changes in the growth rate of the money supply could serve as a leading indicator of stock price changes (Reilly, Brown, 2003).

Successive researchers have also found the relationship between the money supply and stock prices, but these researchers found that money supply growth changes were not leading stock prices but constantly were behind the stock returns by about one to three months.

Another group of studies analyzed relationship to anticipated and unanticipated growth of the money supply. In these researches weekly data on money supply was used. The obtained results showed that stock prices are influenced by money changes, but they quickly adapt to unexpected changes in money growth, hence for investors wishing to enjoy superior returns it is a matter of high importance to prognosticate unanticipated changes in money supply growth. So there is a significant relationship between the real quantity of money (defined as M2) and stock prices: quantity of M2 demanded relative to income is positively related to the deflated price of stocks three quarters earlier and negatively related to the present real stock price (Reilly, Brown, 2003).

Recent studies have found that stock returns are influenced by the monetary environment. The results of these studies have indicated that the results of precedent researches on relationship between stock returns and some company variables or economic variables can be strongly influenced by prevailing monetary environment. A group of researchers showed that the business conditions proxies such as the term spread, dividend yield and default spread, have a different effect on stock returns depending on the prevailing monetary policy, where monetary policy is indicated by discount rate changes (Reilly, Brown,
2003). Their studies also show that the relationship between stock price returns and both size and priceto-book value ratio that was found in several studies only holds during periods of easy monetary policy (Reilly, Brown, 2003), i.e. declining interest rate environment.

The two most important tools of fiscal policy are levels of government expenditures and taxation. An increase in government spending has a stimulative effect on the economy generally or specific segments of it (Cleary, 2001), herewith and share prices; while a cutback in spending has the opposite effect. Conversely, tax increases dampen consumer spending and business profitability, while tax cuts spur the economy and boost profits and common share prices (Cleary, 2001).

Downs and Hendershot analyze impact of the Tax Reform Act of 1986 on stock prices. This act cuts the corporate tax rate, eliminates the investment tax credit and lengthens tax depreciation on structures. Authors find that, these changes should raise equity values by 10 to 13 percent. The rise in stock prices follows from the heavier taxation of new capital and the resulting rise in returns on existing capital. (Downs et al., 1987).

Darrat considers the possibility of changes in fiscal policy (government debt) to exert important effect on stock market and equity returns. In his survey Darrat measures fiscal policy by the real market value of privately held federal debt scaled by potential GNP. His empirical results indicate that fiscal policy plays an important role in determining stock prices in the United States. Specifically the results show, that changes in the stance of fiscal policy have (Darrat, 1990) significant effect on changes in aggregate stock prices during the estimation period (Darrat, 1990) (1961 to 1987). Author claims that the stock market can be seen as an important channel "transmitting the influence of fiscal policy to the real side of the economy" (Darrat, 1990).

It is clear that the general market, as reflected in the major averages, impacts more than half of a stock's price, while earnings account for most of the rest (Andrews, 2004). With this in mind, stock prices should rise with falling interest rates because it becomes cheaper for companies to finance projects and operations that are funded through borrowing. Lower borrowing costs allow higher earnings which increase the perceived value of a stock. Stocks, commodities and existing bond prices tend to rise in a falling interest rate environment (Andrews, 2004). Relationship between interest rates and bond prices is inverse, i.e., an increase in interest rates will cause a decline 
in bond prices and a decline in interest rates will raise bond prices.

Many authors accentuate the depressing effect of inflation on stock prices (Cleary, 2001), as inflationary price pressures create widespread uncertainty and lack of confidence in the future. These factors tend to lower corporate profits (Cleary, 2001). Consequently lower corporate profitability as a result of inflation makes common shares less attractive to investors (Cleary, 2001). As in the case of stocks, inflation causes bond markets to perform poorly. Inflation causes growth of interest rates, and hence bond prices fall. Both stock and bond prices fall in an inflationary environment, mostly because of the anticipated rise in interest rates (Andrews, 2004).

However the relationship between inflation, interest rates and stock prices is not direct and consistent. The reason is that the cash flows from stocks can change along with inflation and interest rates, and we cannot be certain whether this change in cash flows will augment the change in interest rates (Reilly, Brown, 2003). For instance, unexpected inflation can have as well as negative or positive effects on stock returns; this depends on the source of inflation. Here we do not discuss macroeconomic shocks, which affect securities prices crucially (Ewing et al., 2003).

Notably, the actual relationship between inflation, interest rates, and stock prices is an empirical question and the effect varies over time. Therefore, although there has generally been a significant negative relationship between inflation, interest rates, and the returns on stock, this is not always true. In addition, even when it is true for the most of the market, certain industries may have earnings, cash flows, and dividends that react positively to inflation and interest rate changes. In such an instance, their stock prices would be positively correlated with inflation and interest rates (Reilly, Brown, 2003).

The health of the economy has a fundamental influence on share prices because it is ultimately responsible for driving company profits. Broadly speaking, if the economy is growing, company profits improve and shares will become more highly valued. If the economy is weakening, company profits will fall and share prices will go down (London Stock Exchange, 2005).

Nevertheless, as it was mentioned in the very beginning, share prices can rise and fall for a variety of technical reasons that may have nothing to do with the actual outlook for an individual company or the outlook for the market (London Stock Exchange, 2005). Share prices can also be affected by investors who use technical analysis to drive their investment techniques (London Stock Exchange, 2005) as well as by "marketmakers". Technical indicators are rather popular because they are immediate, they are easily understood, and they are reassuring (Thomsett, 1998).

\section{The Main Macroeconomic Variables Affecting Stock Prices of Lithuanian Companies}

In the previous parts the article overviews the main factors that have impact on the performance of stock market and stock prices of particular companies. After examination of theoretical problem the empirical analysis of Lithuanian stock market is executed. This analysis is concentrated on the estimation of country's economical development impact on stock prices of Lithuanian companies. The research tests for relationship between stock prices and economic activity, measured on the basis of following macroeconomic variables reflecting economic situation of Lithuania:

- Foreign direct investment (FDI);

- State budget revenue;

- State budget expenditure;

- Gross domestic product (at current prices) (GDP);

- Price index of consumer goods and services (compared to previous period) (CPI);

- Money (M2);

- Average profitability of governmental bonds;

- Inflation.

By the set of factors authors seek to reflect monetary policy (M2), fiscal policy (state budget revenue and expenditure), alternative risk-free investment measures (governmental bonds), availability of funds for stock-investment (GDP, FDI), rate of change in purchasing power (inflation, CPI).

OMX Vilnius Stock Index (OMXV) - a capitalization weighted chain-linked total-return index, calculated on a continuous basis using the most recent prices of all shares that are listed on the Vilnius Stock Exchange - is being used (Vilnius Stock Exchange, http:/ /www.lt.omxgroup.com). The index base value was set at 100.00 points on January 1, 2000 (Vilnius Stock Exchange, http://www.lt.omxgroup.com). The index is calculated using prices in trading currency (LTL). Officially, till 27 September 2004 Vilnius Stock Exchange used another aggregated index for all listedcompanies LITIN-G. Our analysis is based on quarterly data for the period of 2000 IQ to 2005 IIIQ, calculated for the newly introduced index OMXV. 
In order to determine the relationship between index OMXV and macroeconomic factors the correlation-regression analysis was executed. For this purpose MS Excel program is used. Data used for the analysis is obtained from following sources: OMXV values are taken from Vilnius Stock Exchange web-page (Vilnius Stock Exchange), respectively FDI, state budget revenue and expenditure, GDP, CPI, M2 and inflation rate are obtained from monthly bulletin of Department of Statistics (Lithuanian Department of Statistics, 2006), average profitability of governmental bonds from Bank of Lithuania web-page (The Bank of Lithuania) and quarterly bulletins (The Bank of Lithuania, Quarterly Bulletin). All data are presented in Table 1. Graphical reflection of quarterly data chosen for the analysis is presented in Appendix 1.
First of all, the existence of stochastic relationship between OMXV and variables chosen for the analysis must be estimated. For this purpose correlation coefficients between OMXV and each of the macroeconomic variables are calculated. To evaluate their significance the values of Student criterion ( $t$ ) are calculated and compared with critical value of Student criterion (table-value) $\left(t_{T}\right)$ : if observed value is higher or equal to $t$-critical value $\left(t>t_{T}\right)$ then the relationship is significant and stochastic relationship exists. If $\mathrm{t}<\mathrm{t}_{\mathrm{T}}$ - conclusion about existence of the relationship can not be made and analysis should be continued. Results of executed correlation test are given in Table 2 and Table 3.

Now we are looking for the form and analytical expression of stochastic relationship. This is executed

Table 1. Data for the empirical research of stock prices dependence on macroeconomic variables

\begin{tabular}{|c|c|c|c|c|c|c|c|c|c|}
\hline & Y & $\mathrm{X}_{1}$ & $\mathrm{X}_{2}$ & $\mathrm{X}_{3}$ & $\mathrm{X}_{4}$ & $\mathrm{X}_{5}$ & $X_{6}$ & $\mathrm{X}_{7}$ & $\mathrm{X}_{8}$ \\
\hline Quarters & OMXV & $\begin{array}{l}\text { FDI, } \\
\text { beginning } \\
\text { of period, } \\
\text { Lt mill. }\end{array}$ & $\begin{array}{l}\text { State } \\
\text { budget } \\
\text { revenue, } \\
\text { Lt mill. }\end{array}$ & $\begin{array}{c}\text { State } \\
\text { budget } \\
\text { expendi- } \\
\text { ture, Lt } \\
\text { mill. }\end{array}$ & $\begin{array}{c}\text { GDP at } \\
\text { current } \\
\text { prices, Lt } \\
\text { mill. }\end{array}$ & $\begin{array}{l}\text { CPI as } \\
\text { compared } \\
\text { to } \\
\text { previous } \\
\text { period }\end{array}$ & $\begin{array}{c}\text { Money } \\
\text { M2, } \\
\text { Lt mill. }\end{array}$ & $\begin{array}{c}\text { Average } \\
\text { profitabilit } \\
\text { y of } \\
\text { governmen } \\
\text { tal bonds }{ }^{1}, \\
\%\end{array}$ & $\begin{array}{c}\text { Inflation } \\
\%\end{array}$ \\
\hline 2000 IQ & 102.34 & 8252.1 & 1312.6 & 1530.2 & 10404.7 & 101.6 & 8885.00 & 12.41 & 1.3 \\
\hline 2000 IIQ & 92.66 & 8372.6 & 1472.2 & 1605.1 & 11622.2 & 99.9 & 9334.70 & 12.44 & 0.4 \\
\hline 2000 IIIQ & 92.26 & 8729.0 & 1440.0 & 1559.8 & 11899.2 & 99.6 & 9854.30 & 10.99 & -0.1 \\
\hline 2000 IVQ & 92.70 & 9054.0 & 1556.5 & 1147.1 & 11922.4 & 100.2 & 10455.40 & 9.01 & 0.7 \\
\hline $2001 \mathrm{IQ}$ & 87.39 & 9337.3 & 1633.3 & 1546.1 & 10888.7 & 100.4 & 10611.90 & 8.93 & 0.5 \\
\hline 2001 IIQ & 82.13 & 9549.2 & 1496.7 & 1901.8 & 12238.2 & 101.1 & 10937.60 & 7.41 & 1.3 \\
\hline 2001 IIIQ & 68.81 & 10167.3 & 1536.5 & 1581.9 & 12691.3 & 100.1 & 11712.10 & 7.00 & -0.4 \\
\hline 2001 IVQ & 75.56 & 10458.5 & 1678.2 & 1945.1 & 12744.7 & 100.5 & 12690.60 & 6.07 & 0.6 \\
\hline 2002 IQ & 89.78 & 10661.9 & 2096.8 & 2188.0 & 11318.9 & 100.8 & 12826.50 & 5.56 & 0.1 \\
\hline 2002 IIQ & 83.52 & 10741.8 & 2340.8 & 2422.3 & 13084.7 & 99.1 & 13010.90 & 5.41 & -0.8 \\
\hline 2002 IIIQ & 87.21 & 12048.5 & 2121.7 & 2404.1 & 13810.4 & 98.8 & 13968.80 & 4.99 & -1.4 \\
\hline 2002 IVQ & 84.78 & 12586.7 & 2341.0 & 2997.4 & 13734.5 & 100.3 & 14834.60 & 4.81 & 1.1 \\
\hline 2003 IQ & 96.70 & 13183.8 & 2165.4 & 2264.7 & 12442.5 & 100.1 & 14829.30 & 4.86 & 0.0 \\
\hline 2003 IIQ & 134.97 & 13783.7 & 2229.4 & 2881.6 & 14120.6 & 100.0 & 15581.10 & 4.34 & -0.1 \\
\hline 2003 IIIQ & 176.21 & 14046.4 & 2513.0 & 2539.1 & 14956.4 & 98.6 & 16335.20 & 4.26 & -1.8 \\
\hline 2003 IVQ & 174.48 & 13262.9 & 2716.8 & 3130.0 & 15252.4 & 100.0 & 17536.80 & 4.08 & 0.6 \\
\hline 2004 IQ & 217.8 & 13699.4 & 2332.4 & 2431.3 & 13366.6 & 100.2 & 17949.00 & 3.88 & 0.3 \\
\hline 2004 IIQ & 206.31 & 14363.9 & 2679.5 & 3211.7 & 15346.2 & 101.7 & 18848.10 & 3.66 & 2.0 \\
\hline 2004 IIIQ & 223.71 & 14977.7 & 3261.2 & 2992.4 & 16660.0 & 100.5 & 19601.20 & 3.78 & 0.2 \\
\hline 2004 IVQ & 293.44 & 15365.7 & 3520.9 & 4017.1 & 17067.3 & 100.7 & 21765.50 & 3.43 & 0.4 \\
\hline 2005 IQ & 346.39 & 16192.6 & 3214.3 & 3279.0 & 14734.5 & 100.2 & 23107.70 & 3.11 & 0.6 \\
\hline 2005 IIQ & 413.37 & 17532.7 & 3593.7 & 3785.2 & 17638.6 & 101.0 & 24561.20 & 3.20 & 0.8 \\
\hline 2005 IIIQ & 523.04 & 17538.6 & 3752.1 & 3028.1 & 19070.1 & 100.4 & 25719.50 & 3.50 & 0.8 \\
\hline
\end{tabular}

1 Data from 2000 IQ till 2002 IQ are calculated by the authors of the survey, on the basis of data from the Bank of Lithuania internet page (The Bank of Lithuania, http://www.lb.lt/eng/statistic/index.html); 2002 IIQ - 2005 IIIQ data is taken from quarterly reports of Bank of Lithuania (The Bank of Lithuania, Quarterly Bulletin). 
by search for regression line $\mathrm{Y}_{\mathrm{x} i}=\mathrm{a}_{0}+\mathrm{a}_{1 *} \mathrm{X}_{\mathrm{i}}$, where $i=1,2,3,4,5,6,7,8$. Economical meaning of coefficient $a_{1}$ of the regression line is such - with the change of the macroeconomic variable by one measurement unit, value of OMXV changes by $\mathrm{a}_{1}$ value. By means of MS Excel functions INTERCEPT $\left(a_{0}\right)$ and SLOPE $\left(a_{1}\right)$ coefficients of single linear regression lines were obtained (Table 4).

On the basis of these regression coefficients regression lines were constructed:

$$
\begin{aligned}
& \mathrm{OMXV}^{\wedge}{ }_{\mathrm{x} 1}=-276.12366+0.03591 \cdot \mathrm{X}_{1} ; \\
& \mathrm{OMXV}^{\wedge}{ }_{\mathrm{x} 2}=-157.65136+0.14096 \cdot \mathrm{X}_{2} ; \\
& \mathrm{OMXV}^{\wedge}{ }_{\mathrm{x} 3}=-101.05922+0.10942 \cdot \mathrm{X}_{3} ; \\
& \mathrm{OMXV}^{\wedge}{ }_{\mathrm{x} 4}=-463.94751+0.04579 \cdot \mathrm{X}_{4} ; \\
& \mathrm{OMXV}^{\wedge}{ }_{\mathrm{x}}=-3134.50811+32.93401 \cdot \mathrm{X}_{5} ; \\
& \mathrm{OMXV}^{\wedge}{ }_{\mathrm{x}}=-180.02087+0.02250 \cdot \mathrm{X}_{6} . \\
& \mathrm{OMXV}^{\wedge}{ }_{\mathrm{x} 7}=306.22223-23.31766 \cdot \mathrm{X}_{7} ; \\
& \mathrm{OMXV}^{\wedge}{ }_{\mathrm{x} 8}=157.70614+30.74911 \cdot \mathrm{X}_{8} .
\end{aligned}
$$

To evaluate the adequacy of these analytical expressions to a real situation the F-observed (F) statistic must be calculated and compared to the F-critical value (table-value or $\mathrm{F}_{\mathrm{T}}$ ). If $\mathrm{F}$ is higher than $\mathrm{F}_{\mathrm{T}}$ then the regression line adequately reflects the analysed data. The F-critical value and the F-observed values are represented in the Table 5.

Compared to F-critical, observed Fisher coefficients for regression line $\mathrm{OMXV}^{\wedge}{ }_{\mathrm{x} 1}, \mathrm{OMXV}^{\wedge}{ }_{\mathrm{x} 2}, \mathrm{OMXV}^{\wedge}{ }_{\mathrm{x} 4}$, $\mathrm{OMXV}^{\wedge}{ }_{\mathrm{x}}$ are substantially greater than critical value 2.07. Therefore, these regression equations are use$\mathrm{fu}$ in predicting the value of OMXV index and can be used for planning. Equations which are adequate to real situation are presented in the following graphs (Fig 1-4). Graphs are obtained by means of the program Analyse-it for Microsoft Excel.

\section{Multiple regression analysis}

In the real world all these factors have an aggregate effect on stock prices, which can be estimated by

Table 2. Correlation coefficients between OMXV and macroeconomic variables. Values of t-observed and t-critical

\begin{tabular}{|l|c|c|c|c|c|c|c|c|}
\hline & $\mathrm{X}_{1}$ & $\mathrm{X}_{2}$ & $\mathrm{X}_{3}$ & $\mathrm{X}_{4}$ & $\mathrm{X}_{5}$ & $\mathrm{X}_{6}$ & $\mathrm{X}_{7}$ & $\mathrm{X}_{8}$ \\
\hline $\begin{array}{l}\mathrm{r} \text { (correlation } \\
\text { coefficient) }\end{array}$ & 0.85203 & 0.87113 & 0.69919 & 0.85261 & 0.20555 & 0.91787 & -0.55534 & 0.21478 \\
\hline $\mathrm{t}$ (statistics) & 7.45841 & 8.12944 & 4.48159 & 7.47707 & 0.96251 & 10.59812 & 3.06013 & 1.00777 \\
\hline $\mathrm{t}_{\mathrm{T}}$ (table-value) & 2.07961 & 2.07961 & 2.07961 & 2.07961 & 2.07961 & 2.07961 & 2.07961 & 2.07961 \\
\hline
\end{tabular}

Table 3. Comparison of calculated and critical value of Student criterion

\begin{tabular}{|lll|l|}
\hline $\mathrm{t}\left(\mathrm{Y} / \mathrm{X}_{1}\right)=$ & 7,4584 & $>\mathrm{t}_{\mathrm{T}}=2.07961$ & Stochastic relationship exists \\
\hline $\mathrm{t}\left(\mathrm{Y} / \mathrm{X}_{2}\right)=$ & 8,1294 & $>\mathrm{t}_{\mathrm{T}}=2.07961$ & Stochastic relationship exists \\
\hline $\mathrm{t}\left(\mathrm{Y} / \mathrm{X}_{3}\right)=$ & 4,4816 & $>\mathrm{t}_{\mathrm{T}}=2.07961$ & Stochastic relationship exists \\
\hline $\mathrm{t}\left(\mathrm{Y} / \mathrm{X}_{4}\right)=$ & 7,4771 & $>\mathrm{t}_{\mathrm{T}}=2.07961$ & Stochastic relationship exists \\
\hline $\mathrm{t}\left(\mathrm{Y} / \mathrm{X}_{5}\right)=$ & 0,9625 & $>\mathrm{t}_{\mathrm{T}}=2.07961$ & Stochastic relationship exists \\
\hline $\mathrm{t}\left(\mathrm{Y} / \mathrm{X}_{6}\right)=$ & 10,5981 & $>\mathrm{t}_{\mathrm{T}}=2.07961$ & Stochastic relationship exists \\
\hline $\mathrm{t}\left(\mathrm{Y} / \mathrm{X}_{7}\right)=$ & 3,0601 & $>\mathrm{t}_{\mathrm{T}}=2.07961$ & Stochastic relationship exists \\
\hline $\mathrm{t}\left(\mathrm{Y} / \mathrm{X}_{8}\right)=$ & 1,0078 & $<\mathrm{t}_{\mathrm{T}}=2.07961$ & No conclusion on existence of stochastic relationship \\
\hline
\end{tabular}

Table 4. Single linear regression coefficients

\begin{tabular}{|c|c|c|c|c|c|c|c|c|}
\hline & $\mathrm{X}_{1}$ & $\mathrm{X}_{2}$ & $\mathrm{X}_{3}$ & $\mathrm{X}_{4}$ & $\mathrm{X}_{5}$ & $\mathrm{X}_{6}$ & $\mathrm{X}_{7}$ & $\mathrm{X}_{8}$ \\
\hline $\mathrm{a}_{0}$ & -276.12366 & -157.65136 & -101.05922 & -463.94751 & -3134.50811 & -180.02087 & 306.22223 & 157.70614 \\
\hline $\mathrm{a}_{1}$ & 0.03591 & 0.14096 & 0.10942 & 0.04579 & 32.93401 & 0.02250 & -23.31766 & 30.74911 \\
\hline
\end{tabular}


multiple linear regression analysis. This analysis is a helpful tool in determination of the existence and analytical expression of the aggregate relationship between OMXV index and all, chosen for the analysis, factors. We generated the regression line:

$\mathrm{OMXV}^{\wedge}$ x1, x2, x3, x4, x5, x6, x7, x8 $=\mathrm{a}_{0}+\mathrm{a}_{1} \cdot \mathrm{X}_{1}+\mathrm{a}_{2} \cdot \mathrm{X}_{2}+\mathrm{a}_{3} \cdot$ $X_{3}+a_{4} \cdot X_{4}+a_{5} \cdot X_{5}+a_{6} \cdot X_{6}+a_{7} \cdot X_{7}+a_{8} \cdot X_{8}$.
After execution of calculations by means of MS Excel program's LINEST function the multiple regression line coefficients were obtained (Table 6).

Based on the obtained values of coefficients the regression line is constructed:

$\mathrm{OMXV}_{\mathrm{x} 1, \mathrm{x} 2, \mathrm{x} 3, \mathrm{x} 4, \mathrm{x} 5, \mathrm{x} 6, \mathrm{x} 7, \mathrm{x} 8}^{\wedge}=-1366.38241-0.00844 \cdot \mathrm{X}_{1}-$ $0.00656 \cdot \mathrm{X}_{2}-0.04265 \cdot \mathrm{X}_{3}+0.00450 \cdot \mathrm{X}_{4}+9.22141 \cdot \mathrm{X}_{5}+$ $0.04217 \cdot X_{6}+20.62749 \cdot X_{7}-9.05071 \cdot X_{8}$.

Table 5. Fisher coefficients of single linear regression analysis

\begin{tabular}{|c|c|c|c|c|c|c|c|c|}
\hline & $\mathrm{X}_{1}$ & $\mathrm{X}_{2}$ & $\mathrm{X}_{3}$ & $\mathrm{X}_{4}$ & $\mathrm{X}_{5}$ & $\mathrm{X}_{6}$ & $\mathrm{X}_{7}$ & $\mathrm{X}_{8}$ \\
\hline $\mathrm{F}$ & 3.33165 & 3.786426 & 1.78629 & 3.34377 & 0.95332 & 5.79652 & 1.32019 & 0.9572 \\
\hline $\mathrm{F}_{\mathrm{T}}$ & 2.07331 & 2.07331 & 2.07331 & 2.07331 & 2.07331 & 2.07331 & 2.07331 & 2.07331 \\
\hline
\end{tabular}

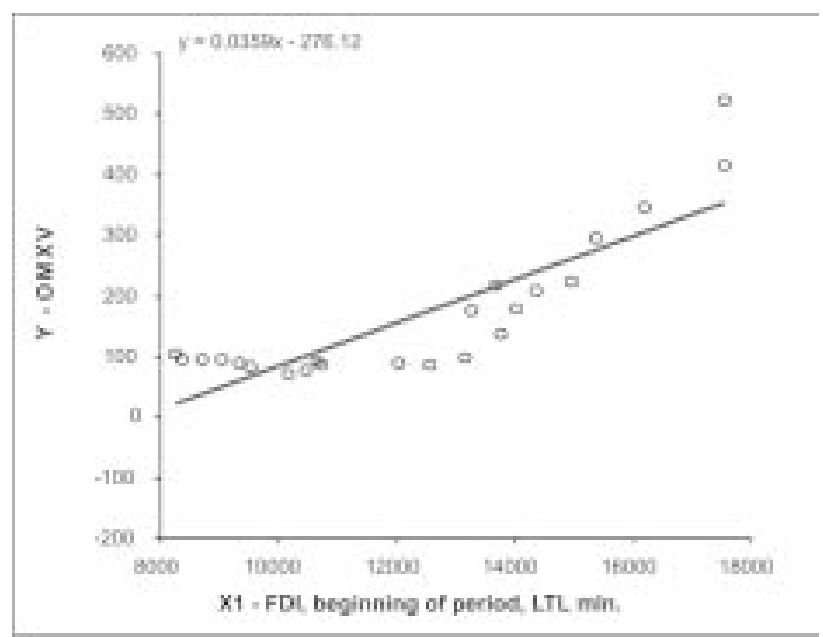

Fig 1. Dependence of OMXV index on FDI (mill. Lt)

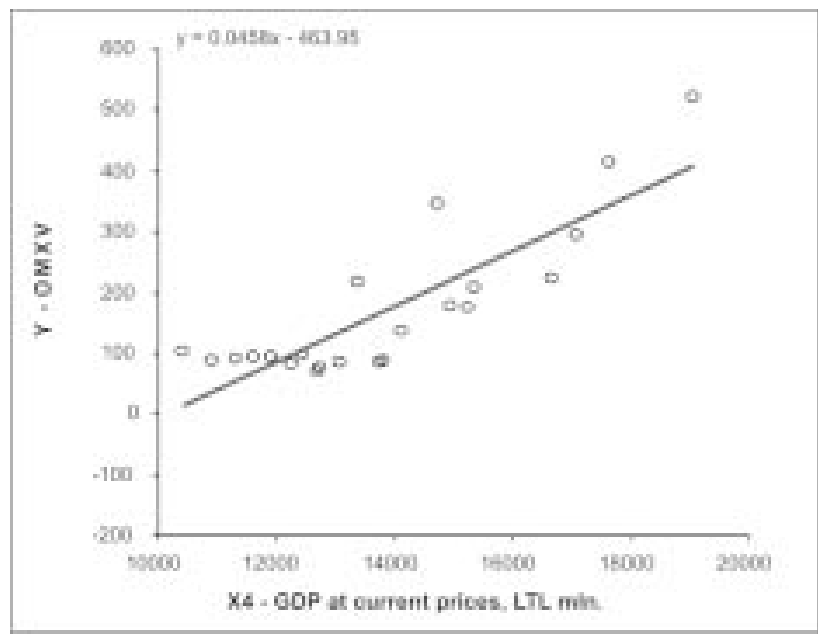

Fig 3. Dependence of OMXV index on GDP (mill. Lt)

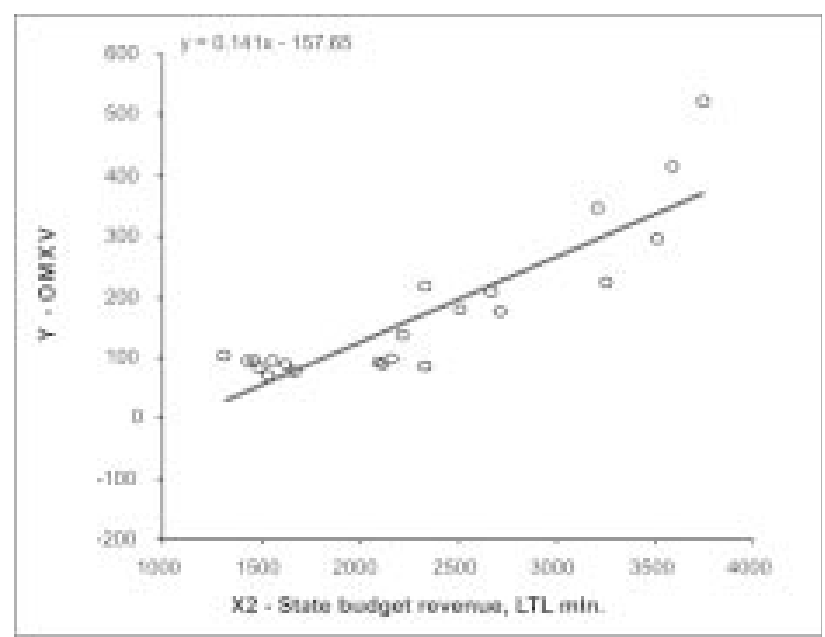

Fig 2. Dependence of OMXV index on state budget revenue (mill. Lt)

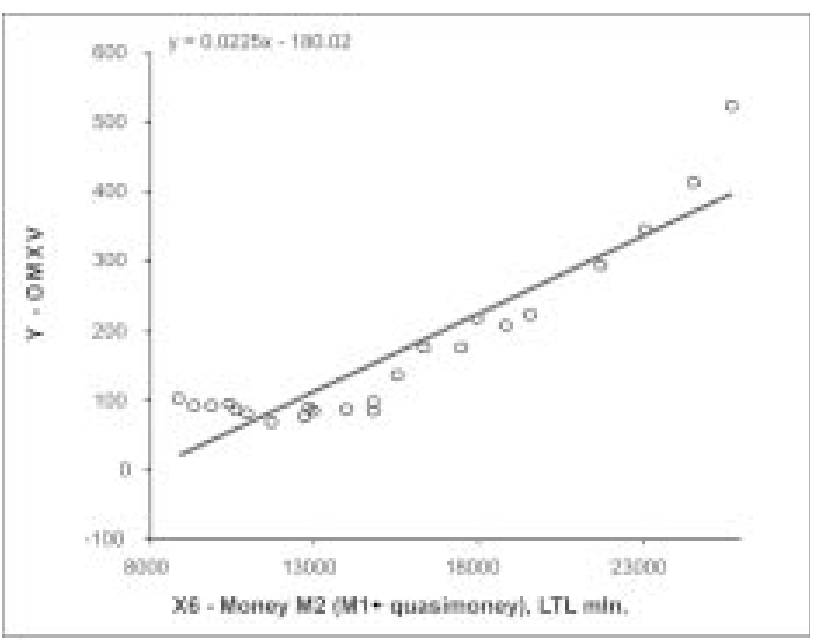

Fig 4. Dependence of OMXV index on M2 (mill. Lt) 
Table 6. Coefficients of multiple linear regression

\begin{tabular}{|c|c|c|c|c|c|c|c|c|}
\hline $\mathrm{a}_{0}$ & $\mathrm{a}_{1}$ & $\mathrm{a}_{2}$ & $\mathrm{a}_{3}$ & $\mathrm{a}_{4}$ & $\mathrm{a}_{5}$ & $\mathrm{a}_{6}$ & $\mathrm{a}_{7}$ & $\mathrm{a}_{8}$ \\
\hline$-1366,38241$ & $-0,00844$ & $-0,00656$ & $-0,04265$ & 0,00450 & 9,22141 & 0,04217 & 20,62749 & $-9,05071$ \\
\hline
\end{tabular}

To estimate adequacy of the obtained analytical expression to the real situation we must calculate and compare Fisher criterion (F) to critical value of Fisher criterion $\left(\mathrm{F}_{\mathrm{T}}\right)$. If our calculated $\mathrm{F}>\mathrm{F}_{\mathrm{T}}$ the conclusion, that regression line describes the situation adequately, can be made. Obtained results (Table 6) obviously point to the adequateness of the found regression line to the real situation. Moreover determination coefficient $\mathrm{R}^{2}$ shows that common regression line explains about $98 \%$ of distribution of OMXV index. This means that index OMXV dependence on chosen for the analysis macroeconomic variables is about $98 \%$. Significance of determination coefficient is proven by calculated value of Student's criterion (27.3), which is higher than t-critical value (2.09) (see Table 7).

The obtained results of the survey let us make a conclusion, that the performance of stock market and stock price changes, is affected by the overall per-

Table 7. Statistics of multiple linear regression analysis

\begin{tabular}{|c|c|}
\hline $\mathrm{F}$ & 40.155 \\
\hline $\mathrm{F}_{\mathrm{T}}$ & 2.203 \\
\hline $\mathrm{R}^{2}$ & 0.975 \\
\hline $\mathrm{t}$ & 27.275 \\
\hline $\mathrm{t}_{\mathrm{T}}$ & 2.093 \\
\hline
\end{tabular}

formance of the economy. Aggregate impact of several macroeconomic factors, chosen for the analysis, explains more than $97 \%$ of changes in stock prices. By being evaluated all together GDP, CPI, M2, average profitability of governmental bonds have positive impact on stock prices; whereas FDI, state budget revenue and expenditure as well as inflation have negative impact.

Hence, stock market reacts to various leading indicator series, the most important of which are money supply, inflation rate, GDP, CPI, FDI, governmental bonds' profitability, etc. As these series tend to "lead the economy", when investors adjust stock prices to reflect expectations for these leading economic series, this makes stock prices a leading series as well.

\section{Conclusions}

We agree that any continuously changing factors are at work to change securities prices in general and prices of various types and groups of securities in particular (Cleary, 2001). Nevertheless, the economy and the stock market have a strong, consistent relationship (Reilly, Brown, 2003).

For many years economists, statisticians, and teachers of finance have been interested in developing and testing models (Fama, 1965) which would explain changes in stock prices. The relationship of stock returns and fundamental variables has been extensively studied through decades. There is a large amount of evidence that short and long-horizon stock price changes, and so returns, are dependent on fundamental variables such as dividend yields. Other studies have found that stock returns are predictable from a whole set of economical variables such as monetary and fiscal policies, interest rates, inflation, the economic and external events, business cycles, technical factors, etc.

Empirical analysis of Lithuanian stock market, concentrated on the estimation of country's economical development impact on stock prices of Lithuanian companies proved the existence of relationship between stock prices, represented by OMX Vilnius Stock Index (OMXV), and economic activity, measured by following macroeconomic variables: foreign direct investment, state budget revenue, state budget expenditure, gross domestic product, price index of consumer goods and services, money supply, average profitability of governmental bonds and inflation. Evaluation of reliability of the obtained results showed that 4 out of 8 obtained single linear regression lines are adequate to real situation; multiple regression line described $98 \%$ of OMXV index distribution.

\section{References}

An investing glossary on the web http:// www.investorwords.com

Andrews, J. A. (2004) Forces that Move Stock Prices. Articles Database http://EzineArticles.com/

Black, F. (1986) Noise. Journal of Finance, Vol 41, p. 529543. 
Cleary, S. (2001) Canadian Securities Exam: Fast-Track Study Guide, Ontario: John Wiley and Sons Canada. 320 p.

Darrat, A. F. (1990) The Impact of Federal Debt upon Stock Prices in the United States. Journal of Post Keynesian Economics, Vol 12, Issue 3, p. 375-389.

Dockery, E.; Vergary, D.; Vergary, F. (2001) Explaining the Behaviour of Stock Prices in an Emerging Market: An Empirical Analysis of the Greek Stock Market. Managerial Finance, Vol 27, No 1, p. 82-98.

Downs, Th.; Hendershott, P. H. (1987) Tax Policy and Stock Prices. National Tax Journal, Vol 40, Issue 2, p. 183-190.

Ewing, B. T.; Forbes, S. M.; Payne, J. E. (2003) The Effects of Macroeconomic Shocks on Sector Specified Returns. Applied Economics, Vol 35, p. 201-207.

Fama, E. F. (1965) Random Walks in Stock Market Prices. Financial Analysts Journal, Vol, 21, No 5, p. 55-59.

Investing internet site http://www.investorguide.com/ igustockmarket.html

London Stock Exchange. What Factors Influence a Share Price? 2005, London Stock Exchange web-page, http:// www.londonstockexchange.com/en-gb/pricesnews/investorcentre/knowledge/investmentfactsheets/influenceshareprice.htm

Reilly, F. K.; Brown, K. C. (2003) Investment Analysis and Portfolio Management. Thomson South-Western, 1248 p.
Russel, P. S.; Torbey, V. M. (2002) The Efficient Market Hypothesis on Trial: A Survey. B-Quest: Journal of applied Topics in Business and Economics of University of West Georgia, http://www.westga.edu/ \%7Ebquest/ 2002/market.htm

Shleifer, A. L.; Summers, H. (1990) The Noise Trader Approach to Finance. Journal of Economic Perspectives, Vol 4, p. 19-33.

Statistics Department of Lithuania. Economic and Social Development in Lithuania (monthly report). Vilnius, 2006, Vol. 1, $176 \mathrm{p}$.

The Bank of Lithuania. Quarterly Bulletin. Vilnius: Lietuvos Bankas, issues from 2002/3Q to 2005/3Q.

Thomsett, A. C. (1998) Mastering Fundamental Analysis. Dearborn Financial Publishing. 256 p.

The Bank of Lithuania. Statistical Data on Lithuanian Economy, http://www.lb.lt/eng/statistic/index.html

Vilnius Stock Exchange. Calculation of OMX Vilnius. Vilnius Stock Exchange web-page, http:// www.lt.omxgroup.com/

Vilnius Stock Exchange. Statistical data on OMXV index history. VSE internet page http://market.lt.omxgroup.com/ $? \mathrm{pg}=\mathrm{charts}$ 
Appendix 1. Dynamics of the analysed data through the period of research (2000 IQ to 2005 IIIQ)
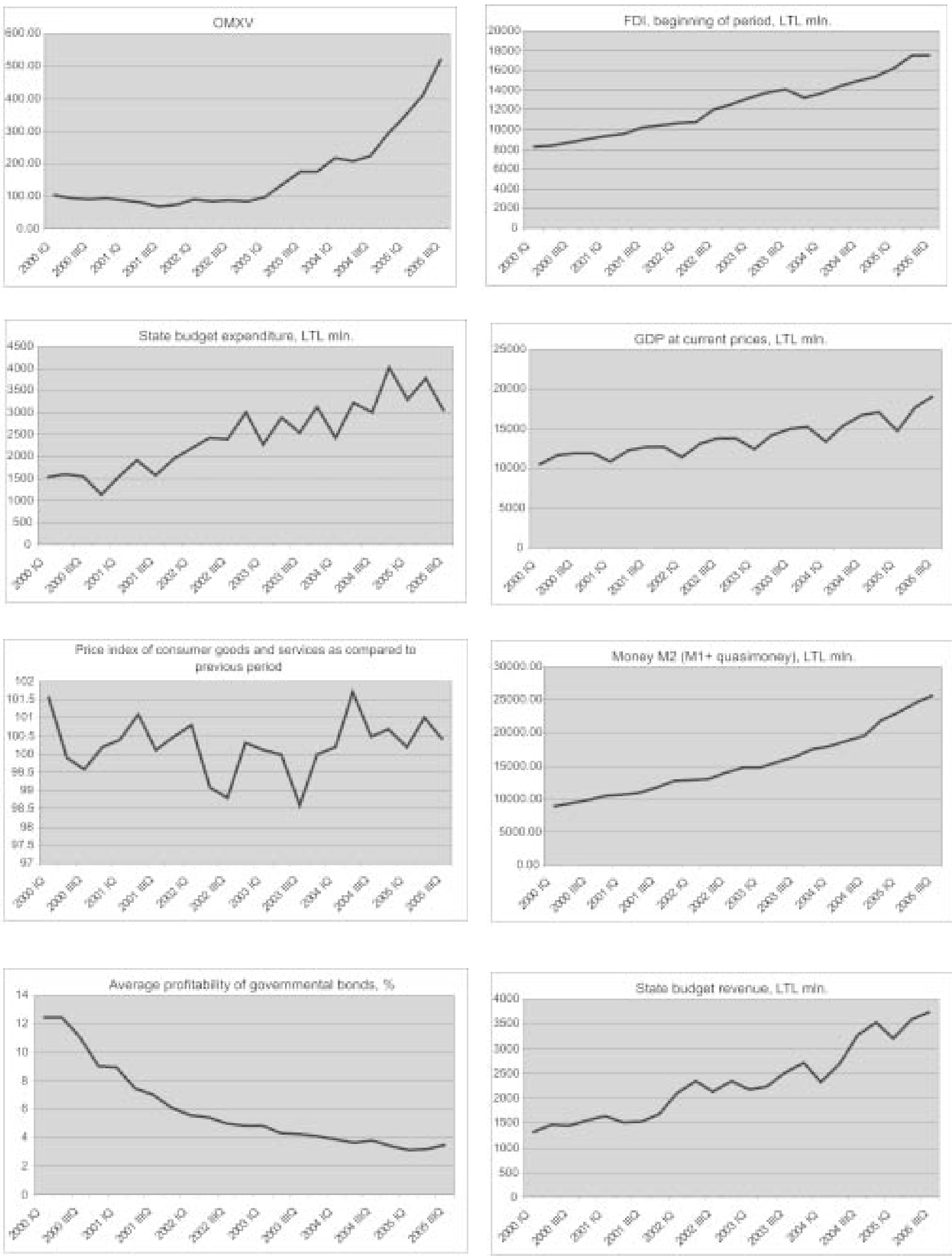